\title{
Taxation of Income of Natural Persons in Selected EU Countries
}

Bajus Radoslav, Ing. PhD.

\author{
Faculty of Economics, Department of Finance, Technical University of Košice, Slovakia
} radoslav.bajus@tuke.sk

Hudáková-Stašová Lenka, Ing. PhD.

Faculty of Economics, Department of Finance, Technical University of Košice, Slovakia lenka.stasova@tuke.sk

Gál Marián Ing. PhD.

Faculty of Economics, Department of Finance, Technical University of Košice, Slovakia marian.gal@tuke.sk

\section{Doi:10.5901/mjss.2015.v6n3s1p77}

\begin{abstract}
In the tax systems of the EU Member States there is a gradual shift of the tax burden from direct to indirect taxes, which should result in the reduction of the tax burden of natural persons and legal entities. But the burden on economy by increasing the indirect taxes leads to the increase of prices. Different states have a different tax structure as well as the level of taxation depending on the economic decisions of the national government. Our intention is to compare the taxation of natural persons' income in the selected EU countries, to examine the diversity of the tax burden, to find out the level of average wages in the particular Member States and on the basis of the obtained data to predict the long-term convergence of the average wage reached in the Slovak Republic (SR) in 2013 to the average in the EU Member States.
\end{abstract}

Keywords: income tax, living wage, minimum wage, tax credit.

\section{Introduction}

The general opinion is that the tax system should be equitable, which means that every taxpayer should pay an equitable share of the costs of the public government. The answers to the questions "What is the right proportion?" and "How to determine it?" vary because defining what is and what is not equitable is very difficult and each group in society has a different opinion on justice.

Tax is characterized as compulsory, by law determined, non-purpose, non-equivalent and regular payment into public money. In relation to tax issues, frequently asked questions about complicates tax, tax rates, etc. are solved. (Hájek, 2013)

The tax system is in practice reflected in the tax system, consisting of a system of taxes applicable in a particular period, in a particular territory, supported by legislation and established in the real practice of taxation. The aim of the tax system in each state is the balanced state of the economy ensured by a constant liquidity of the state in a growing economic environment. (Korečko et al., 2012)

Setting the tax system may influence the manners of the taxpayer. This is manifested by ex-post different methods of tax optimization, whether legally or illegally, or ex - ante adapting endogenous inputs such as working efforts, activities forms, and free motivation to take risks or investment activity. (Vlachý, 2008)

Taxes and the related tax issues are constantly discussed terms of the past, present and future generations. Because there is no standard opinion on the existence, amount or redistribution, we can find a considerable amount differences in taxes all around the world. Therefore, an important aspect of fair taxation is its efficiency. (Hájek, 2013)

The situation in the European Union countries in the field of taxation has gained some dynamics in recent years. On one hand, there is a trend of deepening the coordination and harmonization process and, on the other one, there is an effort to maintain the highest possible level of autonomy in implementing the fiscal policy, a symbol of their national sovereignty and one of the most important tools used to influence the development of the each economy. The proposal to 
harmonize direct taxation is not surprising; it is the continuation of a process that started a log time ago.

In the area of personal income taxes the EU ensures the Member States to have the final word on the income taxation of individuals, so they remain in the responsibility of the national governments, but it is unclear for how long. The situation is not static at all; the development of personal income taxation is constantly in motion. In particular countries the legislation in this field is varied according to the economic, commercial and political changes. We are likely to notice the kind of approximation tendency in the EU.

The opinion on the changes is not harmonized, it has become the centre of attention but it has also been criticized by experts, political representatives, businessmen and other citizens of the particular state. Because the income taxes of natural persons affect every person even if they try to avoid it. People still need some income for their existence that can ensure their basic or other necessities of life and the state needs to take some income in order to provide basic goods to its inhabitants.

The platform of the contribution is the brief identification and comparison of the income tax of natural persons in the selected countries of the European Union. The main goal of this paper is to analyse the relevant regulations governing the taxation of the natural persons' income and in this way to point out the main differences in the taxation system of four EU states. The analysis should give us the answer what trend the selected states have chosen and at the same time to find out the differences in the income with the same starting points. We have analysed the respective applicable tax laws in the EU selected countries and then we used the method of comparison. The comparison is made within the legislative framework of the income tax of natural persons in the particular countries. The secondary goal is to predict the convergence of the average earnings in the SR to the average level of the EU Member States from 2013 based on the research for the achievement of the main goal and on the development of the average wage in the SR since 2004.

\section{Taxation of Income of Natural Persons in the Slovak Republic}

Significant changes in taxation system in the Slovak Republic were implemented with taxation reforms in 1993, 1995, 2004, and finally with the last one in 2013. The taxation reform in 2004 was based on implementation of flat tax rate that was applied in the Slovak Republic before the EU accession and its introduction simplified the taxation system and made it more transparent. The flat tax rate was already cancelled and on 1 January 2013 the progressive income tax rate was implemented again.

The tax base consists of partial bases according to different groups of income. The taxpayer is entitled to deduct the non-taxable part of the tax base only from the partial tax base from employment and from the income from business activities or other self-employment activities or from their total, i.e. from the so-called actively done work depending on the reported tax base. The partial tax base calculated from the so-called passive income (e.g. income from property rental, income from non-monetary prizes, income from the sale of property, income from the payment of share certificate) cannot be reduced by the non-taxable part of the tax base.

If the tax base is equal to or is less than 100 times of the living wages (19,458 EUR in 2013), the non-taxable part is 19.2 times of the living wages (3,735.94 EUR). If the tax base is more than 100 times of the living wages, the nontaxable part is the difference between the 44.2 times of the living wages (8,600.436 EUR) and the quarter of the tax base of the taxpayer; if it is less than zero, the non-taxable part of the tax base per year per taxpayer is zero.

The taxpayer is not eligible to the non-taxable part if he/she receives old-age or retirement pension at the beginning of the tax period. If the amount of the pension is less than 3,735. $94 \mathrm{EUR}$, the taxpayer may apply the difference.

Then the taxpayer may apply 3,735.94 EUR as a non-taxable part for his/her wife/husband, if his/her tax base is less than or equal to 176.8 times of the living wages (34,401.74 EUR). In 2013, the conditions were made more restrictive and the taxpayer may apply this easement only if the wife/husband lives with the taxpayer in the same household and she/he takes care of the dependent minor child in the respective taxation period, she/he receives a cash contribution for the care, she/he is included in the register of job seekers, she/he is deemed to be a citizen with a health disability or she/he is deemed to be a citizen with severe health disabilities.

The taxpayer may apply the tax bonus for each dependent child if in the taxation period he/she had income from employment (job) at least equal to 6 times of the living wages (i.e. 6 × 337.70 EUR $=2,026.20$ EUR) or who had income from business activities or from other self-employment activities of at least 6 times of the living wages (2,026.20 EUR) and reported the tax base (partial tax base) from the income from these activities.. The tax is decreased by the amount of the tax bonus. Only the parents can apply for the tax bonus. (Law of Income Tax Act 595/2003 Coll., as subsequently amended) 


\section{Taxation of Income of Natural Persons in Sweden}

The Scandinavian countries (Denmark, Sweden, Norway, Finland and Iceland) are among the countries that have developed economy, high living standard of their inhabitants and generous welfare systems, so that these countries are considered to be welfare states. They are characterized by high degree of solidarity, but also by high rate of taxation. The taxation systems of the Nordic countries are generally considered to be quite complex, but at the same equitable and efficient. They are known for the application of progressive taxation of natural persons with the highest tax rates in the upper tax brackets in the EU countries. But the high tax burden is abated by the amount of tax allowances and exemptions, as well as by the provision of various social services, particularly in the social field. (Lennerová, 2013). The taxes are managed by the special tax agency Skatteverket that very strictly penalizes tax frauds and the non-payment of taxes. The Swedish Parliament determines the national and state taxes; the local authorities are free to decide on the amount of income tax in their municipalities and districts. The taxpayer pays taxes by depositing funds to his/her tax account, which must be established at the tax administrator. In addition to taxes, there is an extensive system of employee contributions (social security charges) that cover pensions, health benefits and other types of social insurance (Durinová, 2013). The Swedish tax system consists of direct taxes (income tax of natural persons and legal entities, income tax of companies) and indirect taxes (value added tax, excise taxes).

The income tax of natural persons consists of two parts - the local tax (municipal) and from the state tax (national). While the local income tax is the income of particular provinces and levels of the municipal government, the state tax is the income of the state budget. The inhabitants of Sweden are subject to income tax in the area in which they permanently reside.

Every taxpayer who is gainfully employed has his/her own tax account. The tax agency keeps the central register of incomes and assets and the taxpayer receives an already filled-in declaration of taxes from the tax agency. If he/she agrees with it he/she confirms it in writing or by telephone. Taxes are paid in the form of deposits or in the form of tax deductions.

The object of the tax is the income from employment, the income from business activities and from other selfemployment activities and the one from capital property. Table 1 shows the tax rates depending on the level of income.

Table 1: The amount of the taxable income of natural persons in Sweden in 2013

\begin{tabular}{|c|c|c|c|}
\hline Taxable income in SEK & Taxable income in EUR & State tax rate & Average municipal tax \\
\hline up to 426,300 & 49271 & 0 & $31,60 \%$ \\
$426301-604700$ & $49271-69891$ & $20 \%$ & $31,60 \%$ \\
over 604,701 & over 69,891 & $25 \%$ & $31,60 \%$ \\
\hline
\end{tabular}

Source: (http://www.skatteverket.sel, 15 April 2014) (Note: The SEK to EUR conversion is done by the cumulative rate of the ECB in 2013, i.e. 8.652 SEK/EUR)

The local income tax is linear and differentiated by the municipality of the permanent residence of the taxpayer and ranges from $28 \%$ to $35 \%$ (average $31.6 \%$ ). This tax rate consists of two parts: the part for the municipality (in average 20.73\%) and the part for the region (in average 10.82\%). The local income tax is not deductible for purposes of the state income tax. All the taxpayers pay a mortuary in average of $0.22 \%$; its amount varies depending on the particular parish, from the total income tax base of natural persons. The embers of the Swedish or other authorized church pay also a church tax in average of $0.99 \%$ from the total tax base. The rate of this tax is linear and differentiated by the church.

The taxpayers are entitled to a basic allowance (non-taxable part) in the amount of 18,900-34,300 SEK $(2,184-3,964$ EUR) for the taxation period 2013 according to Table 2.

Table 2: Non-taxable portion per taxpayer in Sweden in 2013 - deduction from the tax base per taxpayer for people under 65 years of age

\begin{tabular}{|c|c|c|c|}
\hline $\begin{array}{c}\text { The amount of he annual income } \\
\text { in SEK }\end{array}$ & $\begin{array}{c}\text { The amount of he annual income } \\
\text { in EUR }\end{array}$ & $\begin{array}{c}\text { The amount of the } \\
\text { deduction }\end{array}$ & $\begin{array}{c}\text { The amount of the deduction } \\
\text { in EUR }\end{array}$ \\
\hline$<44,400$ SEK & $<5131 €$ & 18,900 SEK & $2184 €$ \\
$44,500-350,000$ SEK & $\begin{array}{c}5143 €-40453 € \\
350,100 \text { SEK }\end{array}$ & $\begin{array}{c}19,000-34,300 \text { SEK } \\
\text { max. 13,100 SEK }\end{array}$ & $\begin{array}{c}2196 €-3964 € \\
\text { max. } 1514 €\end{array}$ \\
\hline
\end{tabular}

Source: ((http://www.skatteverket.se/, 15 April 2014) (Note: The SEK to EUR conversion is done by the cumulative rate of the ECB in 2013, i.e. 8.652 SEK/EUR) 
They are also entitled to a discount on the active employment activities and if the taxpayer suffers a loss of capital he/she can apply the tax discount in the amount of $30 \%$ of this loss not exceeding the amount of 100,000 SEK (11,558 EUR). If the loss is higher he/she can deduct only $21 \%$ of the loss exceeding the mentioned threshold. The deductible part for the income tax is also a private insurance up to the amount of 12,000 SEK (1,386 EUR).

\section{Taxation of Income of Natural Persons in Great Britain}

Great Britain owns fourteen overseas territories all around the world, which are the last remnants of the former British Empire, but which are not part of the United Kingdom of Great Britain and Northern Ireland, even for tax purposes.

The fiscal year begins on April 6th and ends on April 5th of the following year. The British taxation system is based on the traditional division of direct and indirect taxes. The tax rates for each fiscal period are announced each year together with the presented state budget. The tax system is the same in England, Wales and Scotland. In Northern Ireland there are some exceptions, especially in the system of general taxes.

The main tax office is the "HM Revenue and Customs" (HMRC) and it collects both income taxes of natural persons and legal entities, the capital gains tax, but is also responsible for the collection of the value added tax, excise taxes, customs duties and customs charges. The other types of tax administration and the collection of these taxes belong to the respective government department that administers the particular area.

In Great Britain, there is a tax on the worldwide profit and income for companies registered in Great Britain and for the citizens with a permanent residence. The companies registered outside Great Britain as well as the citizens residing outside the country only pay tax on profit and income which originates in the country. The foreign income of the British tax residents is fully taxable in the place where it originates and the tax paid abroad is deducted from the tax base in Great Britain This is allowed by the use of agreement on avoidance of double taxation that Great Britain concluded with more than 100 countries (http://www.businessinfo.cz/, 20.11. 2014). The British taxation system defines many activities that are subject to income tax of natural persons, but for the purposes of taxation they are divided into three groups: dividend income, income from savings and other income (employment etc.), for which the tax base is separately calculated.

For the purpose of this tax, the income is divided into three categories:

- income from employment,

- income from business activities and other self-employment activities,

- income from domestic dividends,

- income from investments,

- income from immovable property,

- income from abroad.

Other cash or non-cash benefits which are provided by the employer to the employee are also considered to be an income from employment. The example for such income is when employee acquires shares of the company at a discounted price. The income in the form of domestic dividends is taxed at a reduced tax rate because Great Britain applies a partially imputation system for taxing those profits.

Total tax base covers the total sum of the income of taxpayer according to particular types after the deduction of the related expenses and special deductions. The tax base is further reduced by the non-taxable part of the tax base.

The annual tax allowance (personal allowance) for each taxpayer for the taxation period 2013-2014 upto 65 years of age is $9,440 \mathrm{GBP}(11,118$ EUR regardless of the income). For persons $65-74$ years old it is $10,500 \mathrm{GBP}(12,367 \mathrm{EUR})$ for the income up to 24,000 GBP $(28,268$ EUR) and for persons older than 75 years of age it is 10,660 GBP $(12,555$ EUR) for the income up to 24,000 GBP $(28,268$ EUR). The taxpayers can deduct the tax bonus which is $10 \%$ of the following amounts: for spouses 3,040 GBP (3,580 EUR) the tax bonus is 304 GBP (358 EUR) and for spouses of which at least one is older than 74 years of age the tax allowance is 7,915 GBP (9,322 EUR) which is a tax bonus in the amount of 791.5 GBP (932 EUR). The allowance for the blind is 2,160 GBP (2,544 EUR).

Income from dividends is taxed by $10 \%$ rate to the income of $35,000 \mathrm{GBP}(41,224 \mathrm{EUR})$. The income up to 150,000 GBP (up to 176,678 EUR) is taxed by $25 \%$ rate and the income above 150,000 GBP (over 176,678 EUR) by $36.1 \%$ rate. With foreign dividends it is up $40 \%$.

The capital gains tax - in the taxation period 2013-2014, the tax allowance is 10,900 GBP (12,838 EUR). The profit above this limit is taxed at a flat rate $18 \%$ and it is possible to apply the accumulated losses from the previous years (http://www.hmrc.gov.uk/, 18 April 2014).

The taxation of foreign income - everyone who permanently lives in Great Britain imposes a tax also on his/her foreign income. Those who live there for more than 7 years and those who are not permanent residents, pay tax on foreign income transferred to Great Britain. If there is an agreement on avoidance of double taxation between Great 
Britain and the country from which the income comes, it is possible to compensate the applicable foreign tax paid. If these persons (with a permanent residence abroad, but living in Great Britain for a long time) do not want to tax their foreign income, they have to pay an annual flat fee in the amount of 30,000 GBP (35,335 EUR). This does not apply to those who are not 18 years old or have an income up to 2,000 GBP (up to 2,355 EUR). The obligation to file a declaration of taxes for the income tax applies to all who resided in a single year in Great Britain for 183 days or longer. The declaration of taxes is also filed by those people who have spent on average 91 days or more in Great Britain in four consecutive years (http://www.businessinfo.cz/, 20.11. 2014).

The tax rates in Table 3 are divided into lower, basic and higher rate and are progressive. The taxable brackets have been changed every year since 2013 and the income above 150,000 GBP (over 176,678 EUR) and the bonuses over 50,000 GBP (58,892 EUR) are taxable at 45\% rate.

Table 3: Tax rate of the natural persons' income in Great Britain

\begin{tabular}{|c|c|c|}
\hline Rate & Income 2013-2014 in GBP & The amount of the deduction in EUR \\
\hline $20 \%$ & $0-32,010 \mathrm{GBP}$ & $0-37703 €$ \\
$40 \%$ & $32,011-150,000 \mathrm{GBP}$ & $37704-176678 €$ \\
$45 \%$ & over $150,000 \mathrm{GBP}$ & over $176,678 €$ \\
\hline
\end{tabular}

Source: (http://www.hmrc.gov.uk/, 18 April 2014) (Note: The GBP to EUR conversion is done by the cumulative rate of the ECB in 2013, i.e. 0,849 GBP/EUR)

\section{Taxation of Income of Natural Persons in the Czech Republic}

In the past, similarly as the Slovak Republic, also the Czech Republic applied the progressive taxation system with four tax brackets. But in 2008, it passed to system of flat tax rate and super gross wage. Despite this the tax system of the Czech Republic is still considered to be rather complex, containing many exceptions and its essential feature are the tax allowances, better known as tax bonuses.

Since January 2013, the tax administration has been in the responsibility of the Financial Directorate of the Czech Republic which is the ultimate authority of the Ministry of Finances of the Czech Republic.

The structure of taxation system is similar to many other European countries. The primary taxes are divided into direct and indirect and the part of the budget system is also the compulsory insurance and contributions to social and health security.

The taxable income of natural persons is divided into 5 main groups, namely the income from employment and function benefits, the income from business activities and other self-employment activities, the income from capital property, the income from rents and other incomes.

The natural persons can deduce the gained income by the non-taxable part of the tax base but, unlike in Slovakia, they are not of a personal nature, but rather relate to the expenses of everyday life. The basic non-taxable parts include:

- donations to approved educational institutions, political parties or churches in the amount of at least $2 \%$ of the income or 100,000 CZK $(3,849$ EUR) but not more than $10 \%$ of the gained income,

- interests on the mortgage loan for own living up to 300,000 CZK (11,547 EUR) per year,

- contributions to life insurance and additional pension insurance, $\max .12,000$ CZK (max. $461 €$ ),

- contributions paid to labour unions in the amount of $1.5 \%$ of the gained income, but maximum in the amount of 3,000 CZK (115 EUR),

- $\quad$ the non-taxable part in case of disabled citizens.

In addition, the taxpayers can reduce the calculated tax liabilities by several tax credits (Table 4) and per taxpayer, spouse living with the taxpayer in the same household as well as per student preparing for his/her future career. (Law of Income Tax Act 586/1992 Coll., as subsequently amended) 
Table 4: Tax preferences in the Czech Republic in 2013

\begin{tabular}{|l|c|c|}
\hline One-year discount for the: & in CZK & in EUR \\
\hline Taxpayer & 24840 & 956 \\
Spouse with no income & 24840 & 956 \\
Disabled person & 49680 & 1912 \\
Beneficiary of the disability pension for the first and second level of disability & 2520 & 96 \\
Beneficiary of the disability pension for the third level of disability & 5040 & 193 \\
Disabled person & 16140 & 621 \\
Student & 4020 & 154 \\
Tax preferences for the child & 13404 & 515 \\
Disabled person & 26808 & 1031 \\
\hline
\end{tabular}

Source: (http://www.finance.czl, 30.10. 2014) (Note: The CZK to EUR conversion is done by the cumulative rate of the ECB in 2013, i.e. 25.980 CZK/EUR)

\section{Comparison of the Income Taxes in the Selected Countries}

Based on the gained data on the system of income taxation of natural persons we compare the taxation of such income in the Slovak Republic, Sweden, Great Britain and the Czech Republic. The comparison is made with a tax resident, 30year-old IT worker, single and childless, who has been employed by his employer. His annual gross income was 52,011 EUR. The currencies of those countries are recalculated by the ECB rate (cumulative rate, annual average SEK/EUR = 8.652; CZK/EUR = 25.980; GBP/EUR = 0.849). The comparison is shown in Table 5.

Table 5: Net income of the natural person from employment with the same amount of the gross wage in the selected countries in 2013

\begin{tabular}{|c|c|c|c|c|c|}
\hline SWEDEN - Stockholm & SEK & EUR & Czech Republic - Prague & CZK & EUR \\
\hline Gross annual income & 450000 & 52011 & Gross annual income & 1351246 & 52011 \\
\hline Basic allowance & -13100 & -1514 & Super gross wage & 1810669 & 69694 \\
\hline TAX BASE & 436900 & 50497 & TAX BASE & 1351200 & 52009 \\
\hline Municipal tax (29.43\%) & 128580 & 14861 & Health insurance - employee (4.5\%) & 60806 & 2340 \\
\hline State tax (20\%) & 4740 & 547 & Social insurance - employee (6.5\%) & 80759 & 3103 \\
\hline Pension system allowance (7\%) & 31500 & 3640 & Health insurance - employer (9\%) & 121612 & 4680 \\
\hline Funeral allowance and church tax (1.095\%) & 4785 & 553 & Social insurance - employer (25\%) & 310608 & 11955 \\
\hline Discount for the pension system allowance & -31500 & -3640 & Liability tax (7\%) & 7616 & 293 \\
\hline Discount for active employment & -20609 & -2381 & & & \\
\hline INCOME TAX & 117496 & 13580 & INCOME TAX & 210297 & 8094 \\
\hline General wage tax & 141390 & 16341 & Discount per taxpayer & 24840 & 956 \\
\hline Employment tax & 117496 & 13580 & Tax after discount & 185457 & 7138 \\
\hline Net income & 332504 & 38431 & Net income & 1024224 & 39430 \\
\hline Allowance burden & $26,11 \%$ & $26,11 \%$ & Allowance burden & $24,2 \%$ & $24,2 \%$ \\
\hline
\end{tabular}

\begin{tabular}{|c|c||c|c|c|}
\hline SR - Bratislava & EUR & Great Britain - London & GBP & EUR \\
\hline Gross annual income & 52011 & Gross annual income & 44157 & 52011 \\
\hline Contributions - employee (13.4\%) & 6319,44 & Non-taxable portion per taxpayer & 9440 & 11118 \\
\hline TAX BASE & 45691,56 & Contributions - social and health (12\%) & 5298 & 6240 \\
\hline Non-taxable portion of the tax base per taxpayer & 0 & Wage tax 20\% & 5883 & 6929 \\
\hline Tax base & 45691,56 & Net wage & 32976 & 38842 \\
\hline TAX & & & \multirow{2}{*}{$25,32 \%$} & $25,32 \%$ \\
\hline $\begin{array}{c}\text { 19\% from 34,401.74 } \\
\text { 25\% from 11,289.82 }\end{array}$ & 9358,78 & Allowance burden & & \\
\hline Net income & 36332,78 & & & \\
\hline Allowance burden & $30,35 \%$ & & & \\
\hline
\end{tabular}

Source: (own elaboration) 
When comparing the data listed in Table 5 and Figure 1, we can see the employee in SR is the most burdened by the income tax and contributions (30.25\%), he is followed by the employee in Sweden (26.11\%), in Great Britain (25.32\%) the least is the Czech Republic (24.2\%).

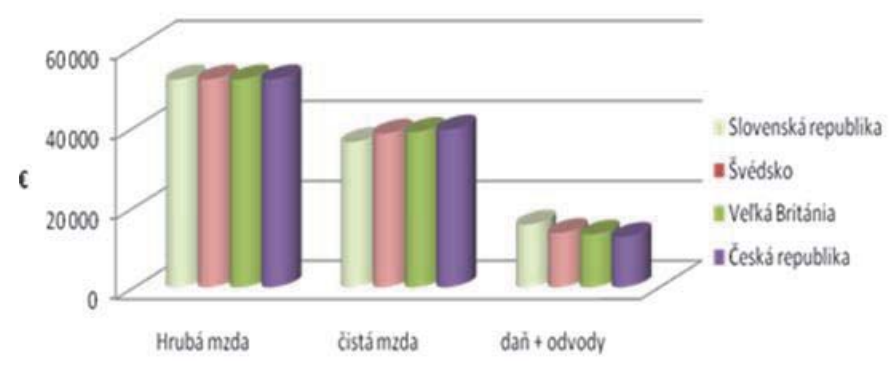

Figure 1: Net income of the natural person

Source: (own elaboration using Table 5). Note: Hrubá mzda - gross wage, čistá mzda - net wage, daň+odvody - tax+ contributions, Slovenská republika - the Slovak Republic, Švédsko - Sweden, Vel'ká Británia - Great Britain, Česká republika - the Czech Republic

\subsection{Tax burden of employees in selected countries in 2013}

In terms of the ratio of total labour costs and the net wages for the employee, $9 \mathrm{EU}$ countries have higher tax and contribution burden on labour than Slovakia. In Figure 2 we can see that the least preferred ratio of the net income on total labour costs in 2013 was achieved in Belgium, France, Austria and Germany, where the total labour cost for employers was at least twice higher compared to the net wages. On the contrary, the best ratio of the total costs on net income was reached in Cyprus, Ireland, Malta and the United Kingdom, where that ratio did not exceed 1.5. In the V4 Group, the tax burden of labour was higher only in Hungary compared to Slovakia.

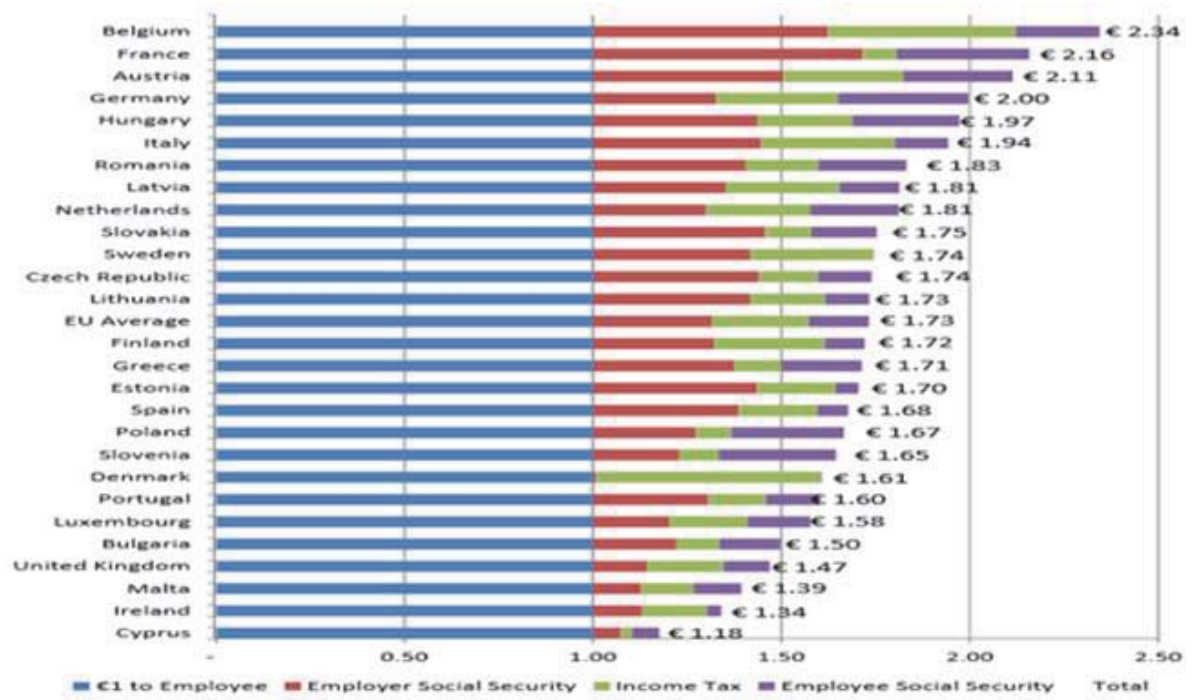

Figure 2: Tax burden of employees

Source: Institut Économique Molinar

\subsection{Total labour cost at $1 €$ net wage in the EU countries}

Slovak people earn less than people in most of developed European states. Therefore, an average Slovak has to work for more than three months to earn the same as an average European. Table 6 shows the average gross incomes of the EU countries in 2013 according to the Eurostat calculations. In the comparison we have to take into account also the other 
side of the coin, i.e. the price level in the country and the cost of living.

Table 6: Average gross monthly wage in the EU/EEA in 2013 in $€$

\begin{tabular}{|c|c|c|c|c|c|}
\hline 1 & Denmark & 4720 & 15 & Slovenia & 1498 \\
\hline 2 & Luxemburg & 4274 & 16 & Malta & 1302 \\
\hline 3 & The Netherlands & 3910 & 17 & Greece & 1124 \\
\hline 4 & Germany & 3695 & 18 & The Czech Republic & 985 \\
\hline 5 & Sweden & 3350 & 19 & Portugal & 972 \\
\hline 6 & Finland & 3217 & 20 & Estonia & 900 \\
\hline 7 & Belgium & 3103 & 21 & Poland & 852 \\
\hline 8 & Ireland & 2981 & 22 & The Slovak Republic & 832 \\
\hline 9 & France & 2651 & 23 & Hungary & 740 \\
\hline 10 & Great Britain & 2410 & 24 & Latvia & 690 \\
\hline 11 & Austria & 2393 & 25 & Lithuania & 624 \\
\hline 12 & Italy & 2029 & 26 & Romania & 476 \\
\hline 13 & Cyprus & 1958 & 27 & Bulgaria & 390 \\
\hline 14 & Spain & 1940 & & & \\
\hline
\end{tabular}

Source: (http://www.eures.sk/clanok_detail.php?id=779/)

People measure their living standard according to the amount of their income and its possibilities for the purchase of goods. In up to eleven EU countries the inhabitants earn on average three times more than the Slovaks. So according to this indicator Slovakia has the twenty-second highest, respectively the sixth lowest living standard in the EU.

\section{Development of the Average Wage in the SR since Its Entry to the EU}

After the EU accession by Slovakia, the people did not an automatic increase of average wages. They assumed that the membership provides an opportunity for active people with higher education or qualification and the wages should grow faster. The offer and demand are decisive and they expected that theses people are certainly demanded. Especially the demand for services may grow - consulting, financial cervices and last but not least the wages of management may grow and these could adapt to the level in the current EU. The development of the average wage in Slovakia after its EU accession is shown in Table 7.

Table no. 7 - Development of the average wage in the SR in 2004-2013€

\begin{tabular}{|c|c|c|c|}
\hline Year & Average monthly wage for the particular year (PM) based on statistics & Interannual growth \\
\hline & SKK monthly & $€$ monthly & $\%$ \\
\hline 2013 & 25065 & 832,00 & 3,4 \\
\hline 2012 & 24251 & 805,00 & 2,4 \\
\hline 2011 & 23679 & 786,00 & 2,2 \\
\hline 2010 & 23167 & 769,00 & 3,3 \\
\hline 2009 & 22429 & 744,50 & 3,0 \\
\hline 2008 & 21782 & 723,03 & 8,1 \\
\hline 2007 & 20146 & 668,72 & 7,4 \\
\hline 2006 & 18761 & 622,75 & 8,6 \\
\hline 2005 & 17274 & 573,39 & 9,2 \\
\hline 2004 & 15825 & 525,29 & $x$ \\
\hline
\end{tabular}

Source: http://onnsmup.dashofer.sk/onn/14/9/2/prakticke-informacie-prehlad-vyvoja-minimalna-mzda

The data in Table 7 show that the average interannual growth of the average wage in the SR in the period 2004-2013 is 5.3\%. Using the information that in 2013 the average wage in the EU Member States was in the amount of 2,000 EUR, it is possible to predict that the average wage in Slovakia, at the same interannual growth than in the period 2004-2013 (5.3\%), levels the current EU average only in 2030 level and that it levels the current highest average wage, which is in 
Denmark (4,720 EUR) only at the end of the first half of this century (2047).

The wages in the Eurozone countries are very diverse, which is largely related to the labour legislation in this area. In the filed of wages the convergence is very slow. On the one hand lower wages are a competitive advantage, but on the other one, they are the negative consequences in the form of a lower real standard of living.

\section{Conclusions}

There are various conditions and aspects that we have to take into account when creating a tax system in every country. It is not possible to expressly say which of the compared systems of personal income taxation is better and which is worse. The Slovak Republic, the Czech Republic, Sweden and Great Britain are different countries with their specific aspects. There are various political, social end economic systems and the tax systems are adapted to them.

Each economical system has to deal with the issue of creating an optimal tax system. Its preparation is a very dynamic process that has to constantly adapt to the internal as well as external conditions of the particular country. There is no ideal tax system that would be simple, equitable and effective at the same time. There will always be a conflict between the efficiency and the equity of the tax system. If there is some effort to achieve higher efficiency of the taxation on the one hand then we will achieve the decrease of equitable taxation on the other one.

Our intention was to compare the taxation of natural persons' income in the selected EU countries, to examine the diversity of the tax burden, to find out the level of average wages in the particular Member States and on the basis of the obtained data to predict the long-term convergence of the average wage reached in the Slovak Republic (SR) in 2013 to the average in the EU Member States.

\section{References}

Bušovská, M., 2014. Convergence of Tax Burden, Tax Revenues and Implicit Tax Rates in the European Union Member States, Ekonomický časopis, 4 (62), pp. 363-376. ISSN 0013-3035

Ďurinová, I., 2013. Daňové systémy krajín Škandinávie, In Biatec, 1/2013. Available at: http://www.nbs.sk/_img/Documents/_PUBLIK_ NBS_FSR/Biatec/Rok2013/06_biatec13-1_durinova.pdf (20.11.2014)

Friedrich, V., Maková, K., Široký, J., 2012. Testing The Predicative Ability of the Tax Progressiveness Indices, E+M Ekonomie a Management, XV (1), pp. 4-16, ISSN 1212 - 3609

Hájek, L., Hamplová, E., Jedlička, P., Kovárník, J., 2013. Vybrané aspekty kauzality daňové incidence. E+M Ekonomie a Management., XVI (4), pp.158-169, ISSN $1212-3609$

Korečko, J., Suhányiová, A., 2012. Daňový systém Slovenskej republiky a jeho postavenie v rámci Európskej únie. 1. vyd. Prešov : Bookman, 2012. 141 s. ISBN 978-80-89568-52-9

Lennerová, I., 2013. Komparácia daňového zat'aženia vo vybraných krajinách. Available at: http://www.derivat.sk/files/2013\%20casopis/ 2013_Jun_Lennerova.pdf (20.11.2014)

Salo, L., Optimization of Tax Loading on the Economy as the Main Direction of Tax Policy Improvement of the Country, Journal of Applied Economic Sciences. Volume VIII, Issue 3 (25), pp. 353-360, ISSN 1843-6110

Sopková, E., Raškovská, K., 2012. The implementation of the concept of corporate social responsibility in the area of income tax in the slovak republic. E+M Ekonomie a Management, XV (2), pp.125-140, ISSN 1212 - 3609

Široký, J., 2010. Daně v Evropské únií, Praha: Linde, ISBN 978-80-7201-799-7

Vlachý, J., 2008. Dynamický model zdanění př́imu fyzických osob. E+M Ekonomie a Management, 3, pp. 85-93 ISSN 1212 - 3609

http://www.skatteverket.se/privat/skatter/beloppprocent/2013.4.2b543913a42158acf800010110.htm|\#h-Beskattningsbarinkomst/ $(15.04 .2014)$

http://www.businessinfo.cz/cs/clanky/dane-z-prijmu-2013-45679.html (20.11.2014)

http://www.hmrc.gov.uk/ (18.04.2014)

https://www.gov.uk/government/publications/rates-and-allowances-income-tax/rates-and-allowances-income-tax\#1b (22.10.2014)

http://www.finance.cz/dane-a-mzda/dane-z-prijmu/dan-z-prijmu-fo/rocni-zuctovani/ (30.10.2014)

http://www.eures.sk/clanok_detail.php?id=779 (18.11.2014)

http://onnsmup.dashofer.sk/onn/14/9/2/prakticke-informacie-prehlad-vyvoja-minimalna-mzda (18.11.2014)

Law of Income Tax Act 595/2003 Coll., as subsequently amended. 